\title{
Differences between urban and rural population with respect to demand on forestry aspects, in a case study of the Turkish province of Balıkesir
}

\author{
Diferenças entre a população urbana e rural em matéria das suas exigências de silvicultura, estudo de caso da \\ província turca de Balıkesir
}

\author{
Seçil Yurdakul Erol ${ }^{\mathrm{I}}$
}

\begin{abstract}
Inhabitants of urban and rural areas are important participants in the process of developing and implementing forest policy. Thus, it is essential to determine their demands and attitudes towards forestry issues. In this context, the demands and evaluation of forest functions are investigated in a case study of the Turkish province of Balıkesir. The findings of the case study show that differences in terms of demands among inhabitants of rural and urban areas are related to forest fires fighting, crimes fighting, forestry-tourism integration, forestation and regeneration activities, and the enlargement of forest areas. The main differences among their assessments of forest functions are related to fire wood production, and the provision of flood and erosion control, nature protection, and recreational opportunities. The findings are important for conflict management and for local decision making. By using the findings of similar studies, the provincial organizations should harmonize their priorities with the expectations of relevant interest groups.
\end{abstract}

Key words: forestry, people demands, forest functions, cluster analysis, comparing means.

\section{RESUMO}

A política de silvicultura da população urbana $e$ rural é uma participante fundamental no processo de formação e execução das florestas. Portanto, é importante determinar as exigências e as aproximações em matéria da silvicultura. A determinação das exigências da população urbana e rural no âmbito desse processo e a interpretação destinada aos assuntos das funções da floresta foram pesquisadas tendo como base a província turca de Balıkesir. As constatações resultantes do estudo na região demonstraram que as diferenças entre as exigências da população urbana e rural em matéria da silvicultura são a luta contra os incêndios florestais, a luta contra os delitos florestais, a integração de silvicultura-turismo, as atividades de reflorestamento e rejuvenescimento da floresta e a ampliação dos campos florestais. Por outro lado, as diferenças fundamentais entre as constatações feitas em matéria das funções da floresta são a produção de lenha, a prevenção de erosão e inundação, a protecção natural, o projeto de recreação. Os resultados obtidos são importantes para a gestão de estudo e para a tomada de decisões no âmbito local. As instituições locais devem adaptar as suas prioridades e as exigências dos grupos interessados tirando proveito das constatações obtidas em estudos semelhantes.

Palavras-chave: silvicultura, exigências da população, funções da floresta, análise de grupamento, comparação das médias aritméticas.

\section{INTRODUCTION}

The most successful natural resource management plans are community based: they involve those who work, live, and recreate on the land itself (DEBRUYCKERE, 2006). These kinds of projects are effective because traditional knowledge of available resources and existing social structures are used to develop more efficient strategies for managing resources (VIRA \& JEFFERY, 2001). Because of this essential perception, participatory methods of developing policy are increasingly common in many areas, including environmental and forest policy (ELSASSER, 2007).

In various international environmental and forest policy agreements, is offered to citizens increased opportunities to participate in making decisions regarding environmental issues, natural resources, and forest

IIstanbul University, Faculty of Forestry, Department of Forest Policy and Administration, 34473 Bahçeköy, Istanbul, Turkey. 
management. Based on the effects of these international processes, public participation can be defined as one of the basic principles and integral elements of recent national forest programs (GLÜCK \& HUMPHREYS, 2002; PÜLZL \& RAMETSTEINER, 2002). In this regard, the equitable participation of stakeholders in decision making and in the resolution of conflicts among interest groups is becoming increasingly important.

In the process of environmental decision making, advocacy of the rights and interests of the general public is often much weaker than advocacy on behalf of other groups (JABBOUR \& BALSILLIE, 2003). SALAM $\&$ NOGUCHI (2006) concluded that indigenous inhabitants of forests, who were of great importance to the success of forestry projects, had little influence on decision-making. RAO et al. (2003) also expressed the importance of investigation into local peoples' aptitude and perceptions in decision making process for natural resources management. Moreover, regular relation between rural people and forestry is seen as the key factor for maintaining systematic and sustainable management of forests (EKIZZOĞLU \& YILDIRIM, 2004). In addition, society is increasingly urbanized. Consequently, it is increasingly important to improve the understanding of inhabitants of urban areas with regard to forestry practices while simultaneously enhancing the understanding of foresters with regard to the urban public's expectations for forests (KONIJNENDIJK, 2000).

Participation of rural and urban people in decision making and implementation processes is also emphasized in recent policy tools of Turkish Forestry. In spite of contrary statements, the participation of rural inhabitants in the development of forestry policy has not been implemented sufficiently. This has caused problems with the planning, decision making, and implementation processes of forest resource management (ÖZTÜRK et al., 2003). The main issues about participation in Turkish forestry can be listed as; i) the public's knowledge about forestry issues is low; various groups of society have different expectations from the forests that may contradict with each other, ii) no incentive systems have been established to encourage participation in the decision-making and implementation process, iii) forest policies, plans, implementations are not known by the public, hence the decision-making process is not transparent iv) neither current legal arrangements nor the organizational structure of the forestry service currently support public participation (AKESEN et al., 2003; ERDÖNMEZ, 2005; ATMIŞ et al., 2007). On the other hand conflicts among interest groups are also common problems in Turkish forestry resource management (BARLI et. al., 2006).
Generally results from preference studies can be useful component in planning multiple-use forest management(GUNDERSEN \& FRİVOLD, 2008). To light this approach, the primary aim of this paper is to characterize the demands of the inhabitants of rural and urbanized areas and to assess the differences between them. This research was conducted in the Balıkesir province of Turkey, which has multi-functional forest resources and urban and rural populations that are approximately balanced.

\section{MATERIAL AND METHODS}

The province of Balıkesir has an especially large potential regarding nature protection, naturebased tourism, outdoor recreation, and natural landscape. On the other hand, the Regional Forest Directorate of Balıkesir, which operates within the borders of the city of Ballkesir, is one of the most important provincial organizations that deal with the production of wood and non-wood forest products in Turkey. Because of its multi-functional forestry structure and its balanced population, Balı kesir Province is chosen as the sample case. On the other hand, demographic properties of the province make it a good sample in context of forestry and community relation. The population of the province of Balıkesir is 1,118,313 according to the 2007 census. The urban population is 649,423 and the rural population is 468,890 (TUIK, 2008). Of the total population, $10 \%$ lives in the forest and 19\% in villages near the forest.

In the first stage, the districts of Balkesir were allocated to different but homogeneous groups using kmeans clustering. Each district was classified in terms of forest area (productive and unproductive forest area), non-wooded area, urban population, rural population (forest villages' population, population of the remaining villages), recreational area, and protected area. Information regarding the distribution of the production of wood and non-wood forest products was not available for districts. Therefore, these data were not used. The data that were used in the cluster analysis, like clusters and distances are shown in table 1. Following two iterations of k-means clustering, three clusters were identified. In light of these results, one representative district was chosen from each of the three groups. These districts were central District, Edremit and Dursunbey (Figure 1).

Then, questionnaires were used as the main method of collecting data. To evaluate demand, 23 statements were used. Eleven statements were used to evaluate forest function. Subjects responded to each statement using a five-point, interval scale in which a value of 5 corresponded to "very important" and a value of 1 corresponded to "unimportant". Members of 
Table 1 - Data related Balıkesir's districts and cluster membership.

\begin{tabular}{|c|c|c|c|c|c|c|c|c|c|c|}
\hline DISTRICTS OF BALIKESİR & 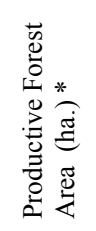 & 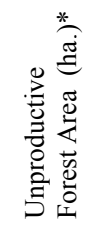 & 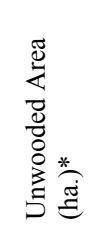 & 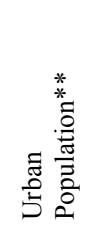 & 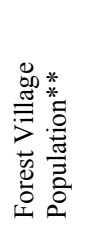 & 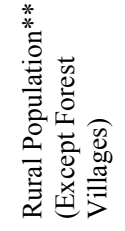 & 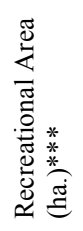 & 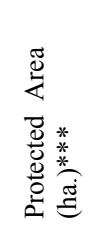 & 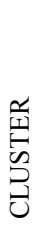 & 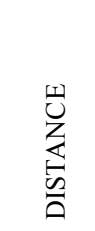 \\
\hline Central Dist. & 6441 & 6453 & 111250 & 215436 & 47767 & 23786 & 25 & - & 1 & 0 \\
\hline Ayvalık & 21711 & 28075 & 10406 & 31986 & 3419 & 23333 & 29 & 17950 & 2 & 21800 \\
\hline Balya & 5828 & 2531 & 45414 & 1916 & 16094 & 859 & - & - & 3 & 14586 \\
\hline Bandırma & 29320 & 28740 & 51541 & 97419 & 6140 & 17194 & - & 23667 & 2 & 75335 \\
\hline Bigadiç & 6294 & 3474 & 42640 & 14550 & 33379 & 2028 & - & - & 3 & 13873 \\
\hline Burhaniye & 73840 & 52166 & 51732 & 31227 & 5490 & 6482 & - & - & 2 & 28777 \\
\hline Dursunbey & 34363 & 5562 & 69194 & 14654 & 32757 & 0 & - & 28189 & 3 & 62988 \\
\hline Edremit & 13379 & 4427 & 30875 & 39202 & 11317 & 33793 & 14 & 21721 & 2 & 37222 \\
\hline Erdek & 776 & 1449 & 8194 & 18626 & 7276 & 6118 & - & 20481 & 2 & 24015 \\
\hline Gömeç & 23944 & 24760 & 20075 & 4122 & 3261 & 3600 & - & - & 2 & 30159 \\
\hline Gönen & 14030 & 11355 & 66496 & 36263 & 28382 & 7159 & - & 2700 & 3 & 30918 \\
\hline Havran & 14142 & 25240 & 30515 & 10122 & 12216 & 4444 & 26 & - & 2 & 23976 \\
\hline İvrindi & 19064 & 31349 & 35718 & 5772 & 23591 & 8528 & 45 & - & 3 & 20348 \\
\hline Kepsut & 8830 & 9751 & 38987 & 5545 & 19463 & 3014 & - & - & 3 & 15936 \\
\hline Manyas & 188 & 6446 & 40019 & 5455 & 10805 & 8888 & - & 64 & 2 & 29401 \\
\hline Marmara A. & 9910 & 15202 & 5066 & 2215 & 1703 & 5528 & - & - & 2 & 37024 \\
\hline Savaştepe & 39304 & 29928 & 17888 & 10288 & 9457 & 3610 & - & - & 2 & 25165 \\
\hline Sindırg1 & 13526 & 12553 & 74068 & 10492 & 28386 & 8906 & - & - & 3 & 28907 \\
\hline Susurluk & 6441 & 6453 & 35021 & 22305 & 13804 & 6998 & - & - & 2 & 18300 \\
\hline
\end{tabular}

(*) Documents of Regional Forest Directorate of Balıkesir-2007, (**)Turkish Statistics Institution-2008, (***)Documents of Balıkesir Provincial Environment and Forest Directorate -2007.

provincial assemblies and town councils represented the urban population. Village headmen represented the rural population (villagers). A total of 102 and 70 inhabitants of rural and urban areas were surveyed.

To evaluate the results of the survey, SPSS (Statistical Package for the Social Sciences) program was used. In the first stage of the evaluation, reliability analysis was conducted to assess the reliability of (a) the interval scale and (b) the estimates of correlation coefficients. The estimates of Cronbach's alpha $(\alpha)$ for the groups of questions were $\alpha=0.78$ and $\alpha=0.69$ respectively. Descriptive statistics that were determined for each variable were the mean and standard deviation. Differences between rural and urban populations were analyzed by Student's t-test.

\section{RESULTS AND DISCUSSION}

Based on descriptive statistics (Table 2), variation in the expectations of forest villagers was related to participation, demand determination and evaluation system, role of forestry sector in regional development, and employment opportunities in forestry sector. Forest fires fighting, forest maintenance, forestation and regeneration activities, forestry-tourism integration, enlargement of forest areas, and forest crime fighting were important subjects for the urban inhabitants. In particular, the last part of the rating forest villagers consisted of forest crimes fighting, forestrytourism integration, forestation and regeneration activities, forest fire fighting, and enlargement of forest areas, respectively. Moreover, the statement regarding the increase of wood production was important to forest villagers but not to inhabitants of urban areas.

The results of t-tests (Table 2) showed that the responses of inhabitants of urban and rural areas differed most $[\mathrm{t}(169)=-12,84]$ for the statement regarding forest crimes fighting. One additional remarkable result was related to the statement that dealt with "integrating tourism and forestry activities in the region" $[\mathrm{t}(170)=-6,40]$. The statement about increase in the production of wood and non-wood forest products was very important to the inhabitants of rural areas but only moderately important to inhabitants of urban areas. Responses of inhabitants of urban and rural areas differed substantially with respect to statements regarding fighting forest fires, forestation and regeneration activities, enlargement forest area, forest maintenance, and biodiversity and nature conservation activities. 


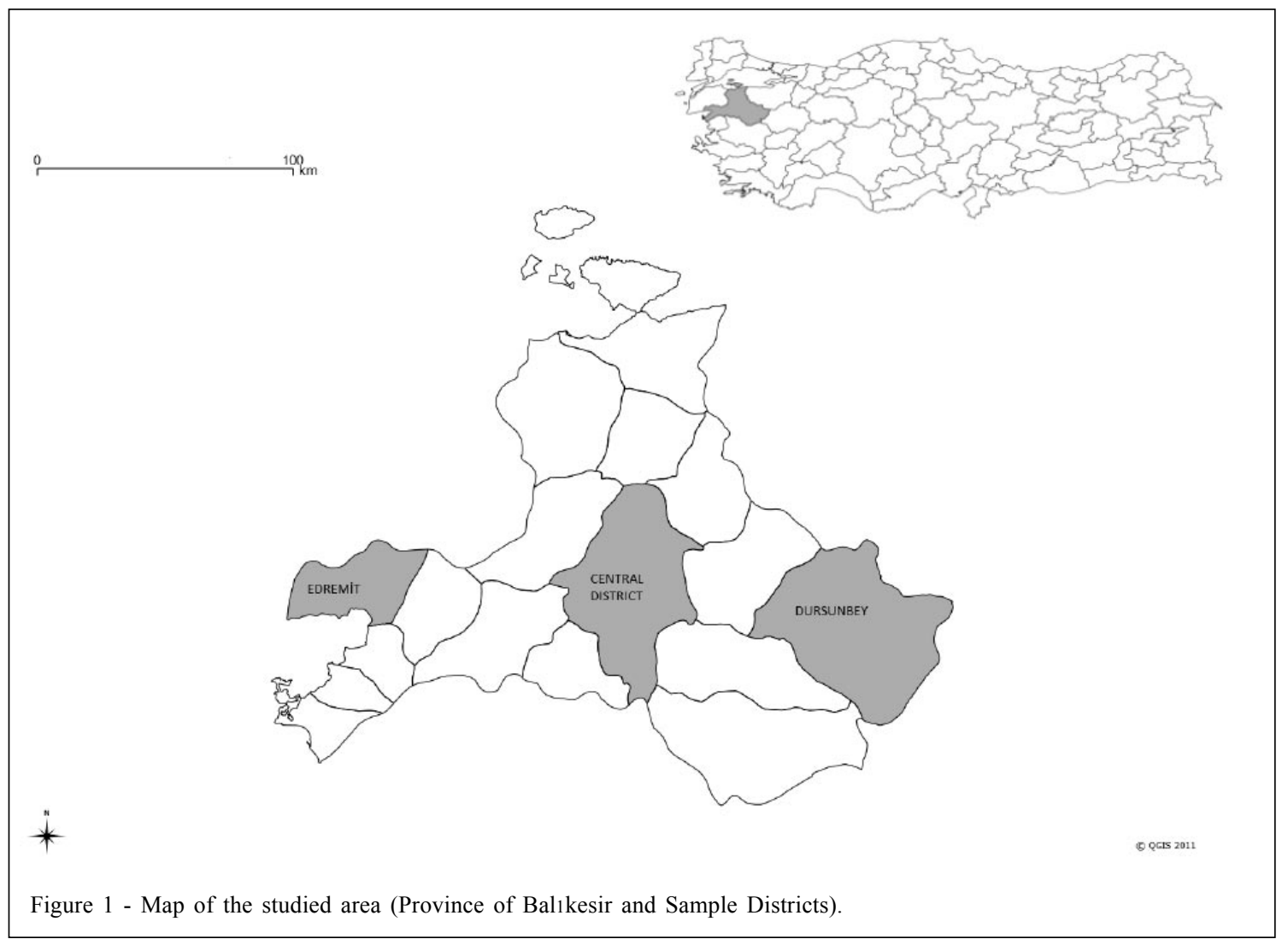

Based on the descriptive statistics, statements regarding water production, climate regulation and community health protection functions assigned a great importance by each group (Table 3 ).On the other hand the biggest difference between the assessments of rural and urban populations was related to the function of nature protection $[\mathrm{t}(170)=-6,03]$. In addition, the function related to firewood was important for rural inhabitants but only moderately important to urban inhabitants $[\mathrm{t}(170)=2,68)]$. Flood and erosion control function of the forests were more important for the urban population than for the rural population $[\mathrm{t}(170)=-3,82]$.

Statements regarding opportunities for recreation were more important for urban inhabitants than for rural inhabitants $[\mathrm{t}(169)=-2,23)]$. The statement regarding "service to science and education" functions of forests also was considered more important to urban than rural people $[\mathrm{t}(170)=-2,91)]$.

There are also some other researches that express the different priorities of urban and rural people. RACEVSKIS \& LUPI's (2006) research results support the idea that rural community members are very concerned about the continued provision of both market and nonmarket forest outputs. While urban community members have milder concerns for sustaining multiple forest outputs but expressed strong concerns for marinating recreational opportunities. ZACHRISSON (2008) found that people living in more rural areas had a slightly different view from urban dwellers about management of protected areas. The mail survey results of CLEMENT \& CHENG (2011) showed that the importance of economic values is greater on more rural forests than on the more urban one. Also they found that people living in more rural municipalities have a more favorable attitude towards human use and interaction with national forests than respondents, who tend to be more urban. ERDÖNMEZ \& ÖZDEN's (2009) research results showed that the rural development project that focuses on meeting the needs of rural population and creating job opportunities influences the migration of people from villages to the cities. On the other hand the most average citizen's interests are focused on conserving forests conserving and on using those places to recreation (KROTT, 2005).

Ciência Rural, v.42, n.3, mar, 2012. 
Table 2 - Descriptive statistics and t-test results ond demands of rural and urban inhabitants.

\begin{tabular}{|c|c|c|c|c|c|c|c|}
\hline \multirow{2}{*}{ STATEMENT } & \multirow{2}{*}{ Participant type } & \multicolumn{3}{|c|}{-----Descriptive Statistics----- } & \multicolumn{3}{|c|}{--------t-test Results------. } \\
\hline & & $\mathbf{N}$ & $\bar{X}$ & $\sigma(s)$ & $\mathrm{t}$ & df & $\mathrm{p}$ \\
\hline \multirow{2}{*}{$\begin{array}{l}\text { Increase participation implements in forestry } \\
\text { activities }\end{array}$} & Rural & 102 & 4,65 & 0,77 & \multirow{2}{*}{2,288} & \multirow{2}{*}{170} & \multirow{2}{*}{0,02} \\
\hline & Urban & 70 & 4,33 & 1,04 & & & \\
\hline \multirow{2}{*}{$\begin{array}{l}\text { Development of public education } \\
\text { opportunities related to forestry }\end{array}$} & Rural & 102 & 3,83 & 1,45 & \multirow{2}{*}{$-2,840$} & \multirow{2}{*}{170} & \multirow{2}{*}{0,05} \\
\hline & Urban & 70 & 4,40 & 0,98 & & & \\
\hline \multirow{2}{*}{$\begin{array}{l}\text { Improve public demand's determination and } \\
\text { evaluation system }\end{array}$} & Rural & 97 & 4,56 & 0,85 & \multirow{2}{*}{2,265} & \multirow{2}{*}{165} & \multirow{2}{*}{0,02} \\
\hline & Urban & 70 & 4,24 & 0,92 & & & \\
\hline \multirow{2}{*}{$\begin{array}{l}\text { Increase the public's knowledge of forestry } \\
\text { activities }\end{array}$} & Rural & 102 & 4,11 & 1,08 & \multirow{2}{*}{$-0,456$} & \multirow{2}{*}{147} & \multirow{2}{*}{0,64} \\
\hline & Urban & 70 & 4,19 & 1,10 & & & \\
\hline \multirow{2}{*}{ Enlarge forest areas } & Rural & 97 & 3,54 & 1,75 & & & \\
\hline & Urban & 70 & 4,43 & 0,95 & $-3,86 /$ & 165 & 0,0 \\
\hline Improve forest fire fighting & Rural & 101 & 3,54 & 1,47 & -5.289 & 168 & 0.0 \\
\hline minprove iorest ine ingiting & Urban & 69 & 4,58 & 0,83 & $-5,289$ & 168 & 0,0 \\
\hline Increase wood production & Rural & 99 & 3,89 & 1,42 & 6.015 & 167 & 0.0 \\
\hline & Urban & 70 & 2,64 & 1,18 & 0,015 & $10 /$ & 0,0 \\
\hline Increase production of non-wood forest & Rural & 100 & 4,13 & 1,39 & & & \\
\hline products & Urban & 70 & 3,34 & 1,37 & 3,365 & 168 & 0,0 \\
\hline Improve forest cadastre and solve ownership & Rural & 102 & 3,79 & 1,68 & & & \\
\hline problems & Urban & 70 & 4,06 & 1,36 & $-1,085$ & 170 & 0,27 \\
\hline Increase enforcement of forestry-related crime & Rural & 102 & 1,86 & 1,47 & -12842 & 169 & 0.0 \\
\hline & Urban & 69 & 4,43 & 0,93 & & & \\
\hline Improve forest maintenance activities & Rural & 100 & 3,96 & 1,16 & $-3,247$ & 168 & 0.0 \\
\hline & Urban & 70 & 4,49 & 0,83 & $-3,24 /$ & 168 & 0,0 \\
\hline Accelerate forestation and regeneration & Rural & 100 & 3,44 & 1,72 & -4648 & 168 & 00 \\
\hline activities & Urban & 70 & 4,49 & 0,89 & $-4,648$ & 168 & 0,0 \\
\hline Develop in-forest transportation and & Rural & 102 & 3,99 & 1,46 & & & \\
\hline construction & Urban & 70 & 4,01 & 1,11 & $-0,123$ & 168 & 0,90 \\
\hline Enable further employment opportunities in & Rural & 102 & 4,39 & 1,15 & 2,517 & 163 & 0.01 \\
\hline forestry activities & Urban & 70 & 3,99 & 0,95 & 2,51/ & 103 & 0,01 \\
\hline Meet the expectations of forest villagers & Rural & 102 & 4,03 & 1,59 & $-0,670$ & 164 & 0,50 \\
\hline regarding forest products & Urban & 70 & 4,16 & 0,89 & $-0,0 / 0$ & 104 & 0, D \\
\hline Improve relations between agriculture- & Rural & 100 & 3,89 & 1,24 & -2708 & 168 & 0.01 \\
\hline breeding and forestry sectors in the region & Urban & 70 & 4,36 & 0,86 & $-2, / 00$ & 100 & 0,01 \\
\hline Integrate tourism and forestry activities in the & Rural & 102 & 3,18 & 1,53 & -6.404 & 170 & 00 \\
\hline region & Urban & 70 & 4,46 & 0,79 & $-6,404$ & $1 / 0$ & 0,0 \\
\hline Develop the current activates related to water & Rural & 102 & 3,98 & 1,36 & $-2,102$ & 170 & 0.03 \\
\hline and soil conservation & Urban & 70 & 4,37 & 0,90 & $-2,102$ & $1 / 0$ & 0,03 \\
\hline Improve bio-diversity and nature & Rural & 102 & 3,83 & 1,21 & $-3,035$ & 166 & 0,00 \\
\hline conservation activities & Urban & 70 & 4,34 & 0,97 & & & \\
\hline Increase the scientific and professional & Rural & 102 & 4,27 & 1,06 & 0.713 & 170 & 0.47 \\
\hline education activities in the region & Urban & 70 & 4,16 & 1,05 & $0, / 10$ & & $0,4 /$ \\
\hline Encourage cooperation between the forestry & Rural & 102 & 4,17 & 1,14 & $0 \cap 031$ & 168 & 0.97 \\
\hline sector and other related sectors & Urban & 70 & 4,17 & 0,88 & $-0,031$ & 108 & 0,97 \\
\hline Increase recreational opportunities in forests & Rural & 102 & 3,62 & 1,56 & $-0,877$ & 170 & 0,38 \\
\hline increase recreational opportunities in rorests & Urban & 70 & 3,81 & 1,25 & $-0,8 / 7$ & $1 / 0$ & 0,38 \\
\hline Improve the role of forestry in regional & Rural & 102 & 4,50 & 1,16 & 1152 & 166 & 0.25 \\
\hline development & Urban & 70 & 4,31 & 0,94 & & & \\
\hline
\end{tabular}

N: total sample size, $\bar{X}$ :arithmetic mean, $\sigma(s)$ : standard deviation, t: observed t value, df: degree of freedom, p: significance level 
Table 3 - Forest function evaluation of rural and urban inhabitants.

\begin{tabular}{|c|c|c|c|c|c|c|c|}
\hline \multirow{3}{*}{ Function } & \multirow{3}{*}{ Participant Type } & \multicolumn{3}{|c|}{ Descriptive Statistics } & \multicolumn{3}{|c|}{ t-test Results } \\
\hline & & & & & & & \\
\hline & & $\mathrm{N}$ & $\bar{X}$ & $\sigma(s)$ & $\mathrm{t}$ & df & $\mathrm{p}$ \\
\hline \multirow{2}{*}{ Timber production } & Rural & 102 & 3,68 & 1,27 & \multirow{2}{*}{$-1,19$} & \multirow{2}{*}{170} & \multirow{2}{*}{0,23} \\
\hline & Urban & 70 & 3,89 & 0,86 & & & \\
\hline \multirow{2}{*}{ Fire-wood production } & Rural & 102 & 3,81 & 1,22 & \multirow{2}{*}{2,68} & \multirow{2}{*}{170} & \multirow{2}{*}{0,0} \\
\hline & Urban & 70 & 3,36 & 0,86 & & & \\
\hline \multirow{2}{*}{ Production of non-wood forest products } & Rural & 102 & 3,76 & 1,41 & \multirow{2}{*}{0,78} & \multirow{2}{*}{170} & \multirow{2}{*}{0,43} \\
\hline & Urban & 70 & 3,61 & 0,90 & & & \\
\hline \multirow{2}{*}{ Water production and water quality protection } & Rural & 102 & 4,23 & 1,05 & \multirow{2}{*}{$-0,89$} & \multirow{2}{*}{170} & \multirow{2}{*}{0,37} \\
\hline & Urban & 70 & 4,76 & 0,76 & & & \\
\hline \multirow{2}{*}{ Flood and erosion control } & Rural & 102 & 3,93 & 1,12 & \multirow{2}{*}{$-3,82$} & \multirow{2}{*}{170} & \multirow{2}{*}{0,0} \\
\hline & Urban & 70 & 4,53 & 0,79 & & & \\
\hline \multirow{2}{*}{ Climate regulation } & Rural & 102 & 4,47 & 0,93 & \multirow{2}{*}{$-0,56$} & \multirow{2}{*}{170} & \multirow{2}{*}{0,57} \\
\hline & Urban & 70 & 4,54 & 0,63 & & & \\
\hline \multirow{2}{*}{ Community health protection } & Rural & 102 & 4,52 & 0,71 & \multirow{2}{*}{$-1,35$} & \multirow{2}{*}{170} & \multirow{2}{*}{0,17} \\
\hline & Urban & 70 & 4,66 & 0,56 & & & \\
\hline \multirow{2}{*}{$\begin{array}{l}\text { Nature protection -biodiversity, wilderness, gene } \\
\text { resources }\end{array}$} & Rural & 102 & 3,72 & 1,1 & 602 & 170 & 0 \\
\hline & Urban & 70 & 4,60 & 0,62 & $-6,03$ & 170 & 0,0 \\
\hline Availobility of recreational onnortunitiec & Rural & 102 & 3,39 & 1,59 & 223 & 160 & 003 \\
\hline Avallability of recreational opportunities & Urban & 69 & 3,87 & 0,92 & $-2,23$ & 169 & 0,02 \\
\hline Contributions to numoldowlonmont & Rural & 102 & 3,85 & 1,03 & 086 & 170 & 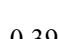 \\
\hline Contributions to rural deveropment & Urban & 70 & 3,99 & 0,92 & $-0,80$ & $1 / 0$ & 0,39 \\
\hline 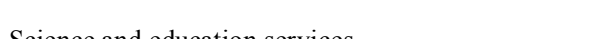 & Rural & 102 & 3,55 & 1,11 & 201 & 170 & 00 \\
\hline Science and education services & Urban & 70 & 4,04 & 0,90 & $-2,91$ & 170 & 0,0 \\
\hline
\end{tabular}

N: total sample size, $\bar{X}$ :arithmetic mean, $\sigma(s)$ : standard deviation, t: observed t value, df: degree of freedom, P: significance level.

In conclusion, determining the expectations and priorities of the public could become a more important part of the decision making process for Turkey. Currently, mechanisms to solicit the active participation of the public are underdeveloped. Certainly, other interest groups, such as forest products enterprises, non-governmental organizations, and other related public institutions, should participate in the process of forestry administration. However, the general public has a special position among all stakeholders because of the size of the community and because of the relationship of the general public with the forests.

In reality, forests are useful to society in many ways, any one of which may not be completely taken into consideration by any single stakeholder. Some of the more complex issues may require a specific knowledge, which should not be linked to any kind of social interest (KOUPLEVATSKAYA-YUNUSOVA \& BUTTOUD, 2006). Thus, the goal should be to structure a decision such that the knowledge of the technical experts can inform the citizen participants, while the knowledge of the citizen participants can inform the technical professionals (STEELMAN, 2001). Thus, various sections of society can play complementary roles in forest management(BUCHY \& HOVERMAN, 2000).
The findings of this case showed that probable conflicts are related to fighting forest fires and crime, forestry-tourism integration, forestation and regeneration activities, and the enlargement of forest areas. The evaluation of forest functions probably differ between both populations. To light these findings, it is clear that information sharing regarding forest activities and the priorities of forestry organization and public relations activities is important.

\section{CONCLUSION}

Expectations clearly differed between inhabitants of urban and rural areas. Thus, the expectations of interest groups and conflicts could be determined separately for each of the forestry units. The collected data then should be included in local decision making processes.

\section{ACKNOWLEDGEMENTS}

This research is supported by Istanbul University Research Fund, (Istanbul Üniversitesi Bilimsel Arastirma Projeleri Yurutucu Sekreterligi), by project number UDP-6322/ 15032010 .

Ciência Rural, v.42, n.3, mar, 2012. 


\section{REFERENCES}

AKESEN, A. et al. Ormanc1likta katılım: ormanc1l1k politikası açıs ından bir değerlendirme (participation in forestry: an assessment from view of forest policy). In: NATIONAL FORESTRY CONGRESS, 2., 2003, Ankara. Proceedings... Ankara:Türkiye Ormancı lar Dernøgi, 2003. p.38-48.

ATMIŞ, E. et al. Public participation in forestry in Turkey. Ecological Economics, v.62, p.352-359, 2007. Available from: $<$ http://www.sciencedirect.com/science/article/pii/ S0921800906003363>. Accessed: Nov. 09, 2009. doi: 10.1016/ j.ecolecon.2006.07.002.

BARLI, O. et al. Analytical approach for analyzing and providing solutions for the conflicts among forest stakeholders across Turkey. Forest Policy and Economics, v.9, p.219-236, 2006. Available from: <http:/www.sciencedirect.com/science/article/ pii/S1389934105000882>. Accessed: Jun. 12, 2008. doi: 10.1016/j.forpol.2005.07.009.

BUCHY ,M.; HOVERMAN, S. Understanding public participation in forest planning: a review. Forest Policy and Economics, v.1, p.15-25, 2000. Available from: <http://www.sciencedirect.com/ science/article/pii/S138993410000006X>. Accessed: May 15, 2008. doi: 10.1016/S1389-9341(00)00006-X.

CLEMENT, J.M.; CHENG, A.S. Using analysis of public value orientations, attitudes and preferences to inform national forest planning in Colorado and Wyoming. Applied Geography, v.31, p.393-400, 2011. Available from: <http://www.sciencedirect.com/ science/article/pii/S0143622810001165>. Accessed: Jul. 03, 2011. doi:10.1016/j.apgeog.2010.10.001.

DEBRUYCKERE,L. A. Changing the paradigm-effectively engaging stakeholders in forest policy issues. Journal of Forestry, v.104, n.6, p.335-336, 2006. Available from: $<$ http:/ /www.createstrat.com/i/paradigmarticle.pdf $>$. Accessed: Sep. 18, 2009 .

EKİZOĞLU, E.; YILDIRIM, H.T. Demirköy ve İğneada çevresinde orman-halk ilişkileri. (Forest-public relationship in Demirköy and İgneada regions). Review of the Faculty of Forestry, University of Istanbul, Series B, v.54, n.1, p.3743, 2004.

ELSASSER, P. Do "stakeholders" represent citizen interests? An empirical inquiry into assessments of policy aims in the National Forest Programme for Germany. Forest Policy and Economics, v.9, p.1018-1030, 2007. Available from: <http:// ww w.sciencedirect.com/science/article/pi / S1389934106001699>. Accessed: Sep. 10, 2009. doi: doi:10.1016/j.forpol.2006.10.002.

ERDÖNMEZ, C. Türk Ormancı lığı ve Kat111m: Sorular ve Yan1tlar. (Turkish Forestry and Participation: questions and answers. In: SYPOSIUM ON URGENT COURSE OF ACTIONS IN TERMS OF ASPECTS AND LEGAL ARRANGEMENTS IN THE INTERNATIONAL PROCESS AND REFLECTIONS TO ORGANIZATIONS, 2005, Ankara. Proceedings... Ankara: Orman Mühendisleri Odas' ${ }^{1}$, 2005. p.325-335.

ERDÖNMEZ, C.; ÖZDEN, S. Relations between rural development projects and urban migration: the Köykent Project in Turkey. Ciência Rural, v.39, n.6, p.1873-1879, 2009. Available from: $<$ http://www.scielo.br/scielo.php?script=sci_arttext\&pid=S0103- 84782009000600037\&lng=en\&nrm=iso $>$. Access: Sep. 2, 2010. doi: $10.1590 / \mathrm{S} 0103-84782009005000091$.

GLÜCK, P.; HUMPHREYS, D. Research in National Forest Programmes in a European context. Forest Policy and Economics, v.4, p.253-258, 2002. Available from: <http:// www.sciencedirect.com/science/article/pi / S1389934102000680>. Accessed: Nov. 22, 2008 doi: 10.1016/ S1389-9341(02)00068-0.

GUNDERSEN, V.S.; FRIVOLD, L.H. Public preferences for forest structures: a review of quantitative surveys from Finland, Norway and Sweden. Urban Forestry \& Urban Greening, v.7, p.241-258, 2008. Available from: <http:// www.sciencedirect.com/science/article/pi i/ $\mathrm{S} 161886670800023 \mathrm{X}>$. Accessed: Oct. 29, 2009. doi: 10.1016/ j.ufug.2008.05.001.

JABBOUR, J.R.; BALSILLIE, D. The effectiveness of public participation in forest management: a case study analysis of Morice Innovative Forest Practices Agreement. Forest Chronicle, v.79, n.2, p.329-341, 2003. Available from: <http:/ /pubs.cif-ifc.org/doi/pdf/10.5558/tfc79329-2>. Accessed: Nov. $13,2008$.

KONIJNENDIJK, C.C. Adapting forestry to urban demands role of communication in urban forestry in Europe. Landscape and Urban Planning, v.52, p.89-100, 2000. Available from: $<\mathrm{http}: / / \mathrm{www}$.sciencedirect.com/science/article/pii/ S0169204600001250>. Accessed: Jun. 12, 2008. doi: 10.1016/ S0169-2046(00)00125-0.

KOUPLEVATSKAYA-YUNUSOVA, I.; BUTTOUD, G. Assessment of an iterative process: the double spiral of re-designing participation. Forest Policy and Economics, v.8, p.529-541, 2006. Available from: <http://www.sciencedirect.com/science/ article/pii/S1389934105000766>. Accessed: Nov. 21, 2008. doi: 10.1016/j.forpol.2005.07.010.

KROTT, M. Forest policy analysis. Netherlands: Springer, 2005. 317 p.

ÖZTÜRK, A. et al. Türkiye Orman Kaynakları Yönetiminde Kat1 l1mc1 l1k. (Participation in Turkish Forest Resources Management). In: NATIONAL FORESTRY CONGRESS, 2., 2003, Ankara. Proceedings... Ankara: Türkiye Ormancılar Derneği, 2003. p.344-359.

PÜLZL, H.; RAMETSTEINER, E. Grounding international modes of governance into National Forest Programmes. Forest Policy and Economics, v.4, p.259-268, 2002. Available from: $<$ http://www.sciencedirect.com/science/article/pii/ S1389934102000692>. Accessed: Oct. 16, 2007. doi: 10.1016/ S1389-9341(02)00069-2.

RACEVSKIS, L.A.; LUPI, F. Comparing urban and rural perceptions of and familiarity with the management of ecosystems. Society \& Natural Resources, v.19, n.6, p.479495, 2006. Available from: <https://www.msu.edu/user/lupi/ Racevskis_Lupi_SNR_2006.pdf>. Accessed: Feb. 06, 2008. doi: $10.1 \overline{0} 80 / 0 \overline{8} 9419 \overline{2} 0600663862$.

RAO, K.S. et al. Local peoples' knowledge, aptitude and perceptions of planning and management issues in Nanda Devi Biosphere Reserve, India. Environmental Management, v.31, n.2, p.168-181, 2003. Available from: <http:// www.springerlink.com/content/tvnfhu6kcnuh48tt/fulltext.pdf $>$. Accessed: Feb. 09, 2008. doi: 10.1007/s00267-002-2830-4. 
SALAM, M.A.; NOGUCHI, T. Evaluating capacity development for participatory forest management in Bangladesh's Sal forests on '4Rs' stakeholder analysis. Forest Policy and Economics, v.8, p.785-796, 2006. Available from: <http:// www.sciencedirect.com/science/article/pi i/ S1389934105000237>. Accessed: Feb. 22, 2008. doi: 10.1016/ j.forpol.2004.12.004

STEELMAN, T.A. Elite and participatory policymaking: finding balance in a case of national forest planning. Policy Studies Journal, v.29, n.1, p.71-89, 2001. Available from: <http:// onlinelibrary.wiley.com/doi/ $10.1111 /$ j. 1541 0072.2001.tb02075.x/pdf>. Accessed: Apr. 19, 2007. doi: 10.1111/j.1541-0072.2001.tb02075.x.

TUIK (TURKISH STATISTICS INSTITUTION). Adrese Dayal Nüfus Kayıt Sistemi-2007 Nüfus Sayımı Sonuçları (Addressı Based
Populat1on Reg1strat1on System.- 2007 population Census in Turkey)., 2008. Available from: <http://tuikapp.tuik.gov.tr/ adnksdagitimapp/adnks.zul>. Accessed: Dec. 02, 2008.

VIRA, B.; JEFFERY, R. Introduction: analytical issues in participatory natural resources management. In: VIRA, B.; JEFFERY, R. Analytical issues in participatory natural resource management. Palgrave: Macmillian, 2001. p.1-19.

ZACHRISSON, A. Who should manage protected areas in the Swedish mountain region? A survey approach to- co-management. Journal of Environmental Management, v.87, p.154-164, 2008. Available from: <http://www.sciencedirect.com/science/ article/pii/S0301479707000357>. Accessed: Oct. 29, 2009. doi: $10.1016 /$ j.jenvman.2007.01.010 